\title{
ANALISIS PREFERENSI TERHADAP SOSIODEMOGRAFI PADA PASIEN UMUM INSTALASI RAWAT JALAN RSUD BDH SURABAYA 2016
}

\author{
Titin Wahyuni* \\ *Prodi D3 RMIK, STIKES Yayasan Rs. Dr. Soetomo \\ Email : titinwahyuni@gmail.com
}

\begin{abstract}
ABSTRAK
Preferensi pasien menjadi penting saat sebuah pelayanan kesehatan ingin mengembangkan produk. Preferensi sendiri dimata konsumen merupakan sebuah pelayanan yang lebih efektif, lebih murah dan lebih cepat. Penelitian ini dilakukan dengan latar belakang masalah adanya jumlah penurunana pasien pada tahun 2015 dan peningkatan jumlah keluhan pada tahun yang sama. Penelitian ini dilakukan dengan menggunakan faktor sosiodemografi yang terdiri dari usia, pendidikan, pendapatan, jumlah anggota keluarga yang menjadi tanggungan dan penananngung biaya pengobatan. Preferensi dilakukan terhadap empat indikator yaitu sikap memprioritaskan rumah sakit sebagai pilihan utama, kemauan merekomendasikan, melakukan word of mouth positif, dan pemanfaatan ulang. Penelitian ini menggunakan rancangan potong lintang dengan tehnik survei. Unit analisis adalah pasien umum instalasi rawat jalan RSUD BDH. Waktu penelitian adalah Juni- Agustus 2016. Tehnik sampling menggunakan purposive sampling, dengan jumlah sebanyak 85 responden.

Hasil dari penelitian ini adalah Preferensi pada indikator prioritas sikap memprioritaskan sebagai pilihan utama, kemauan merekomendasikan dan word of mouth memiliki kecenderungan berbeda antara sikap dan kemauan yang baik dan tidak baik, sedangkan pada indikator kemauan pemanfaatan ulang cenderung kurang berbeda.Preferensi paling baik menurut faktor sosiodemografi terdapat pada indikator usia 20 - 30 tahun, tingkat pendidikan SMA, tingkat pendapatan 2,1-3 juta, jumlah anggota yang menjadi tanggungan kurang dari 2, dan menanggung sendiri biaya pengobatannya. Kesimpulan yang didapat penelitian secara umum preferensi penelitian ini dapat dikatakan baik. Indikator yang perlu mendapat perhatian khusus adalah kemauan untuk pemanfaatan ulang.
\end{abstract}

Kata Kunci : Preferensi, Pasien Umum, Sosiodemografi

\section{ABSTRACT}

Patient preference becomes important when a healthcare servicewould like to develop existed product aor a new one. According to consumers, preference is a service that more effective, cheaper and faster in service. This research was conducted with the background of their problems decrease number of patients in 2015 and an increase in the number of complaints in the same year. This study was conducted using sociodemographic factors consisting of age, education, income, number of family members and dependents penananngung medical expenses. Preferences conducted on four indicators : hospitals prioritize attitude as the main selection, willingness to recommend, doing positive word of mouth, and reusing. Design of this study was a cross sectional study. Unit of analysis was non NHI's outpatients who ever visit BDH hospital. Collection data was taken on June to 
August in 2016 used a purposive sampling with a total 85 respondents. Results from this study is the preference in priority indicator as the main option to prioritize, willingness to recommend and word of mouth have different tendencies between attitude and willingness good and not good, while at the whim indicators tend to be less different reuse. Most excellent preference according to sociodemographic factors contained in the indicators of age 20-30 years old, high school education level, income level from 2.1 to 3 million, the number of members who are dependents of less than 2, and bear the cost of treatment. The conclusion, preference seem in a good way in generally. Indicators that needs special attention is the willingness to reuse.

Key word : $\quad$ Preference, Non-National Health Insurance's Patients, Sociodemographic

\section{PENDAHULUAN}

Rumah Sakit Umum Daerah Bhakti

Dharma Husada merupakan rumah sakit tipe C yang sedang berkembang di wilayah Surabaya Barat, selanjutnya akan disebut sebagai RSUD BDH. Dibangun oleh pemerintah kota Surabaya dengan tujuan meningkatkan derajat kesehatan masyarakat, meningkatkan akses pelayanan kesehatan yang terjangkau oleh masyarakat, dan terbangunnya lingkungan serta perilaku yang sehat.

Pada tahun 2015, terjadi penurunan kunjungan sebesar 30,80\% dibandingan dengan tahun 2014, yaitu sebesar 38,49\%. Penurunan pasien umum Rawat Jalan kemungkinan disebabkan mereka telah bermigrasi menjadi pasien BPJS. Namun data tentang jumlah keluhan pasien yang meningkat pada tahun 2015 menunjukkan adanya ketidakpuasan terhadap pelayanan RSUD BDH juga menjadi salah satu kemungkinan penyebab penurunan jumlah pasien umum pada tahun 2015.
Peningkatan jumlah keluhan pada tahun 2015 menunjukkan, ketidakpuasan tertinggi pada jam kedatang dokter yang tidak tepat waktu dan waktu pelayanan yang dianggap lama. Ketidak puasan lain yang juga dikeluhkan adalah pelayanan rumah sakit yang kurang memuaskan, dan diikuti dengan pelayanan yang dianggap lama.

Penelitian menunjukkan bahwa kepuasan konsumen merupakan faktor terpenting dalam mencapai kesetiaan (Oliver, 1999). Kesetiaan juga merupakan capaian terhadap upaya mempertahankan konsumen lama. Sedangkan menciptakan konsumen baru lebih sulit dibanding dengan mempertahankan pasien lama. Upaya mempertahankan konsumen pada penelitian industri jasa hanya sebesar 25\% daripada biaya untuk menarik konsumen baru. Sedangkan dari sisi probabilitas, mempertahankan konsumen pada industri jasa adalah lebih dari 60\% sedangkan menarik konsumen baru kurang dari 30\% 
(Clancy dan Shulman, 1994 dalam Tjiptono F, 2007). Oleh sebab itu setiap pemberi fasilitas pelayanan kesehatan seharusnya menciptakan "hambatan" untuk beralih ke pemberi fasilitas pelayanan kesehatan sehingga akan membuat pasien menjadi berpikir ulang saat hendak memutuskan untuk beralih ke rumah sakit lain. Kendati demikian mempertahankan konsumen lama bukan sesuatu yang mudah. Indeks kepuasan konsumen pada industri jasa yang tinggi bukan jaminan dapat mempertahankan konsumen. Penelitian Hoffman dan Bateson, 1997 mengindikasikan bahwa konsumen lama yang sebenarnya mengalami kepuasan dan sangat puas yaitu sebesar 65\% sampai dengan $85 \%$ justru beralih ke penyedia jasa lain.

Berdasarkan hal itulah maka penulis bermaksud melakukan penelitian tentang loyalitas konsumen rawat jalan RSUD BDH yang diukur melalui preferensi dengan indikator prioritas utama, rekomendasi, word of mouth positive dan pembelian ulang.

\section{METODE}

Penelitian ini menggunakan rancangan potong lintang dengan tehnik survei. Unit analisis penelitian adalah pasien Instalasi rawat Jalan RSUD BDH Surabaya. Waktu penelitian pada Bulan Juni-Agustus 2016.
Tehnik sampling menggunakan purposive sampling dengan kriteria sampel pada penelitian sebagai berikut :

a. Responden adalah pasien umum atau yang dapat mewakili responden

b. Responden adalah pasien yang sudah pernah menggunakan RSUD BDH Surabaya

Pada penelitian ini sampel yang diperoleh saat penelitian berjumlah 100 responden, akan tetapi saat dilakukan proses editing data ada beberapa data dari responden yang tidak dapat digunakan sehingga peneliti menggunakan data yang bisa digunakan. Sampel yang tersisa dari pengurangan data yang tidak bisa digunakan ada 85 responden.

\section{HASIL DAN PEMBAHASAN}

Pada hasil dan pembahasan akan disajikan empat indikator preferensi yaitu rumah sakit pilihan utama, kemauan merekomendasikan, word of mouth positif dan pemanfaatan ulang. Pada akhir hasil dan pembahasan akan ditampilkan tabulasi silang dari sosiodemografi terhadap preferensi yang berupa penilaian komposit menjadi dua kategori preferensi baik dan tidak baik. 
Tabel 1.1 Distribusi Frekuensi Sikap Responden Untuk Memprioritaskan RSUD BD Sebagai Rumah Sakit Pilihan Utama Untuk Berobat

\begin{tabular}{|l|c|c|}
\hline Pilihan & Jumlah & $\%$ \\
\hline Sangat setuju & 6 & 7,1 \\
\hline Setuju & 62 & 72,9 \\
\hline Tidak setuju & 17 & 20 \\
\hline Sangat tidak setuju & 0 & 0 \\
\hline Total & 85 & 100 \\
\hline
\end{tabular}

Sebagian besar responden sebagain besar bersikap baik yaitu sebesar 71,9\% menyatakan setuju dan $7,1 \%$ menyatakan sangat setuju untuk memprioritaskan RSUD BDH sebagai rumah sakit pilihan untuk berobat. Hal dapat dimaknai bahwa responden mengutamakan untuk memilih RSUD BDH sebagai tujuan berobat. Dengan kata lain, RSUD BDH merupakan pilihan utama diantara beberapa pilihan lain dalam evaluasi alternatif responden. RSUD BDH merupakan rumah sakit yang

Tabel 1.2. Distribusi Frekuensi Kemauan Responden Untuk Merekomendasikan RSUD BDH Kepada Orang Lain

\begin{tabular}{|l|c|c|}
\hline Pilihan & Jumlah & $\%$ \\
\hline sangat bersedia & 6 & 7,1 \\
\hline bersedia & 67 & 78,8 \\
\hline tidak bersedia & 12 & 14,1 \\
\hline sangat tidak bersedia & 0 & 0 \\
\hline Total & 85 & 100 \\
\hline
\end{tabular}

Frekuensi kemauan responden

untuk merekomendasikan RSUD BDH kepada orang lain dapat dikatakan baik, hal ini dibuktikan 78,8\% menyatakan bersedia dan $7,1 \%$ menyatakan sangat bersedia.Hal ini berarti responden memiliki kepuasan yang dirasakan mendapat kepercayaan dan memiliki derajat kepentingan yang tinggi dan merupakan harapan ideal responden akan suatu pelayanan kesehatan (Solomom,2001 dalam Kotler et al, 2008). Hal ini kemungkinan karena instalasi rawat jalan juga dianggap sebagai keputusan yang memiliki risiko kecil, kemungkinan operasi seandainya ada juga bukan jenis operasi besar (Baurer, 1974 dalam Kotler et al, 2008).

sehingga melalui hal tersebut maka timbul rasa percaya kepada RSUD BDH. Kepercayaan tersebut itulah yang kemungkinan menyebabkan responden memiliki kemauan untuk merekomendasikan RSUD BDH kepada orang lain. 
Tabel 1.3. Distribusi Frekuensi Kemauan Responden Untuk Melakukan Word Of Mouth Positive Kepada Orang Lain

\begin{tabular}{|l|c|c|}
\hline Pilihan & Jumlah & $\%$ \\
\hline sangat bersedia & 1 & 1,2 \\
\hline bersedia & 52 & 61,2 \\
\hline tidak bersedia & 32 & 37,6 \\
\hline sangat tidak bersedia & 0 & 0 \\
\hline Total & 85 & 100 \\
\hline
\end{tabular}

Word of mouth positive adalah kemauan ini sangat penting dalam pengukuran responden untuk menyebarluaskan preferensi karena merupakan indikator pengalaman positifnya. Pada penelitian ini, adanya pemanfaatan produk rumah sakit responden dapat dikatakan memiliki yang lain, sehingga akan meningkatkan kemauan yang baik untuk melakukan word profitabilitas rumah sakit. of mouth positive. Word of mouth positive

Tabel 1.4. Distribusi Frekuensi Kemauan Responden Untuk Melakukan Pemanfaatan Ulang Ke RSUD BDH

\begin{tabular}{|l|c|c|}
\hline Pilihan & Jumlah & $\%$ \\
\hline sangat bersedia & 3 & 3,5 \\
\hline bersedia & 45 & 52,9 \\
\hline tidak bersedia & 35 & 41,2 \\
\hline sangat tidak bersedia & 2 & 2,4 \\
\hline Total & 85 & 100 \\
\hline
\end{tabular}

Pemanfaatan ulang merupakan terhadap merek tertentu.Pada penelitian indikator dimana konsumen yang puas ini, pemanfaatan ulang tidak terlalu kemudian memanfaatkan kembali. Frase berbeda antara yang bersedia untuk pemanfaatan ulang sering dihubungkan melakukan pemanfaatan ulang.Untuk yang dengan loyalitas merek. Meskipun mulai bersedia sebesar 56,4; dan yang sebenernya keduanya berbeda. Loyalitas tidak bersedia sebesar 43,6. Hal ini berrati merek lebih menggambarkan komitmen perlu pengkajian tindak lanjut, apakah psikologis terhadap merek tertentu, pemanfaatan ulang lebih bersifat inersia sedangkan pembelian ulang merupakan atau loyalitas sesuangguhnya. perilaku pembelian ulang yang sama

Tabel 1.5. Distribusi Frekuensi Sosiodemografi Responden Terhadap Preferensi

\begin{tabular}{|l|c|c|}
\hline \multirow{2}{*}{ Sosiodemografi } & \multicolumn{2}{|c|}{ Preferensi } \\
\cline { 2 - 3 } & \multicolumn{2}{|c|}{ Jumlah (\%) } \\
\hline Usia (tahun) & Baik & Tidakbaik \\
\hline$<20$ & $9(10.59)$ & $0(0)$ \\
\hline $20-30$ & $27(31.76)$ & $5(5.88)$ \\
\hline $31-40$ & $16(18.82)$ & $6(7.06)$ \\
\hline
\end{tabular}




\begin{tabular}{|c|c|c|}
\hline $41-50$ & $14(16.47)$ & $3(3.53)$ \\
\hline di atas 50 & $3(3.53)$ & $2(2.35)$ \\
\hline \multirow{2}{*}{ Total (\%) } & $69(81.18)$ & $16(18.82)$ \\
\hline & \multicolumn{2}{|c|}{$85(100)$} \\
\hline Pendidikan & Baik & Tidakbaik \\
\hline SD & $4(4.71)$ & 1 (1.18) \\
\hline SMP & $3(3.53)$ & 1 (1.18) \\
\hline SMA & $43(50.59)$ & $9(10.59)$ \\
\hline Sarjana & 19 (22.35) & $5(5.88)$ \\
\hline \multirow{2}{*}{ Total (\%) } & $69(81.18)$ & $16(18.82)$ \\
\hline & \multicolumn{2}{|c|}{85 (100) } \\
\hline Pendapatan (juta) & Baik & Tidakbaik \\
\hline di bawah 1 & 15 (17.65) & $0(0)$ \\
\hline $1 \mathrm{~s} / \mathrm{d} 2$ & $15(17.65)$ & $8 \quad(9.41)$ \\
\hline $2.1 \mathrm{~s} / \mathrm{d} 3$ & 19 (22.35) & $4(4.71)$ \\
\hline $3.1 \mathrm{~s} / \mathrm{d} 4$ & $16(18.82)$ & $2(2.35)$ \\
\hline di atas 4 & $4(4.71)$ & $2(2.35)$ \\
\hline \multirow{2}{*}{ Total (\%) } & $69(81.18)$ & $16(18.82)$ \\
\hline & \multicolumn{2}{|c|}{85 (100) } \\
\hline $\begin{array}{l}\text { Jumlah anggota keluarga yang } \\
\text { menjadi tanggungan }\end{array}$ & Baik & Tidakbaik \\
\hline$<2$ & $21(24.71)$ & 7 (8.24) \\
\hline 2 & $17(20)$ & $5(5.88)$ \\
\hline 3 & $20(23.53)$ & $2(2.35)$ \\
\hline 4 & $6(7.06)$ & $2(2.35)$ \\
\hline 5 & $5(5.88)$ & $0(0)$ \\
\hline \multirow{2}{*}{ Total (\%) } & $69(81.18)$ & $16(18.82)$ \\
\hline & \multicolumn{2}{|c|}{85 (100) } \\
\hline
\end{tabular}

\begin{tabular}{|l|c|c|}
\hline \multirow{2}{*}{ Sosiodemografi } & \multicolumn{2}{|c|}{ Preferensi } \\
\cline { 2 - 3 } Penanggung biaya pengobatan & Baik & Tumlah (\%) \\
\hline Sendiri & $53(62.35)$ & $15(17.65)$ \\
\hline Biaya keluarga & $12(14.12)$ & $1(1.18)$ \\
\hline Asuransi & $3(3.53)$ & $0(0)$ \\
\hline Sumber lain & $1(1.18)$ & $0(0)$ \\
\hline \multirow{2}{*}{ Total (\%) } & $69(81.18)$ & $16(18.82)$ \\
\cline { 2 - 3 } & & $85(100)$ \\
\hline
\end{tabular}

Berdasarkan data pada tabel di atas, preferensi paling baik terdapat pada rentang usia 20-30 tahun yaitu sebesar 27\%. Secara umum preferensi pada indikator usia dapat dikatakan baik dengan perbandingan preferensi sebesar $\mathbf{8 1 . 1 8} \%$ dan tidak baik sebesar $\mathbf{1 8 . 8 2} \%$.

Preferensi responden berdasarkan indikator pendidikan dapat dikatakan baik, dengan perbandingan $\mathbf{8 1 . 1 8} \%$ baik, dan tidak baik 18.82\%. Preferensi paling baik 
terdapat pada tingkat pendidikan SMA. Sedangkan yang paling tidak baik terdapat pada tingkat pendidikan SMP.

Preferensi responden berdasarkan indikator pendidikan dapat dikatakan baik, dengan perbandingan $\mathbf{8 1 . 1 8} \%$ baik, dan tidak baik 18.82\%. Preferensi paling baik terdapat pada tingkat pendapatan 2,1 sampai dengan 3 juta, dan paling tidak baik terdapat pada pendapatan 1 sampai dengan 2 juta.

Jumlah anggota keluarga yang menjadi tanggungan menunjukkan beban ekonomi yang ditanggung oleh responden. Berdasarkan data di atas dapat kita ketahui, preferensi paling baik terdapat pada kelompok responden yang jumlah anggota keluarga yang menjadi tanggungan kecil yaitu kurang dari 2, yaitu sebesar 2,71\% sedangkan yang paling tidak baik berada pada kepompok responden yang memiliki jumlah anggota tanggungan 5orang.

Jika dilihat dari indikator penanggung biaya pengobata, preferensi paling baik terdapat pada kelompok responden yang membiayai sendiri pengobatannya, yaitu sebesar 62,35\% dan yang paling tidak baik terdapat pada kelompok responden asuransi dan sumber lain.

Hasil penelitian menunjukkan adanya kecenderungan responden dengan kepuasan diikuti dengan kesetiaan meskipun nilai kepuasan (perceived service quality) lebih tinggi dibandingkan dengan nilai preferensi. Hasil dari penelitian berarti sesuai dengan penelitian Gunawan, K., Djati, S.P. (2011) yang melakukan penelitian pada rumah sakit umum swasta di Singaraja-Bali. Pada penelitian tersebut ditemukan secara simultan terdapat pengaruh positif dan signifikan antara dimensi kualitas pelayanan terhadap loyalitas pasien. Hal ini juga sesuai dengan Pisgin A., Atesoglu I. (2015). Ruyter, Ko de, Wetzels, M. (1998) menyatakan kepuasan berpengaruh signifikan terhadap kesetiaan konsumen dengan switching cost sebagai variabel antara. Secara umum kepuasan merupakan faktor yang berpengaruh terhdap kesetiaan konsumen pada pelayanan jasa menurut Hau LN, Thuy PN. (2012) dan Tong C, Wong SKS, Lui KPH. (2012). Sedangkan menurut Wong $\mathrm{R}$, Tong $\mathrm{C}$, Wong $\mathrm{A}$. (2014) yang melakukan penelitian pada konsumen asuransi kesehatan di Hongkong bahwa tingkat kepuasan menentukan pencapaian tingkat kesetiaan.

\section{KESIMPULAN}

Pada penelitian ini, yang dapat kami simpulkan adalah :

1. Preferensi pada indikator prioritas sikap memprioritaskan sebagai pilihan utama, kemauan merekomendasikan dan word of mouth memiliki kecenderungan berbeda antara sikap 
dan kemauan yang baik dan tidak baik, sedangkan pada indikator kemauan pemanfaatan ulang cenderung kurang berbeda.

2. Preferensi paling baik menurut faktor sosiodemografi terdapat pada indikator usia 20 - 30 tahun, tingkat pendidikan SMA, tingkat pendapatan 2,1-3 juta, jumlah anggota yang menjadi tanggungan kurang dari 2, dan menanggung sendiri biaya pengobatannya.

\section{DAFTAR PUSTAKA}

Ayabakan S, Zheng Z, Bardhan I, Kirksey $K$. Value of Health Information Sharing in Reducing Healthcare waste : An Analysis of Duplicate Testing Across Hospitals. July 2014 [Cited 2017 Feb 25]. Available from : https://simonexchange.rochester.e du/home/researchseminars/20070 8\%20\%20201415\%20Seminar\%2 0Papers/2014-15/1-

Fall\%202014/Health\%20Info\%20 Sharing\%20Paper\%20July\%2020 14.pdf.

Burnham T.A., J.K. Frels, V. Mahajan. Consumer Switching Costs : A Typology, Antecendants, and Consequence. Journal of The Academy of Marketing Science. 2003; 31 (2): 109-126.

Gunawan, K., Djati, S.P. Kualitas Layanan dan Loyalitas Pasien (Studi pada Rumah Sakit Umum Swasta di Kota Singaraja-Bali). Jurnal Manajemen dan Kewirausahaan. 2011; 13 (1): 32-39.
Hau LN. Thuy PN. Impact of Service Personal Values on Service value and Customer Loyalty : A CrossService Industry Study. Service Business. 2012; 6 (2) : 37-155.

Hoffman K.D., Bateson J.E.G. Eseentials of services marketing. Fourt Worth : The Dryden Press; 1997

Hooley G., Piercy NF., Nicoulaud B. Marketing Strategy and Competitive Positioning. 4th Ed. Edinburgh : Pearson Education Limeted; 2008.

Odin Y., N. Odin, P. Valette-Florence. Conceptual and OperationalAspects of Brand Loyalty: An Empirical Investigation. Journal of Business Research. 2001; 53 : 460-469.

Oliver R.L. Whence Customer Loyalty. Journal Marketing. 1999; 63: 3344.

Pisgin A., Atesoglu I.The Effects of Customer Satisfaction and Switching Cost on Customer Loyalty in Healthcare. Journal of Business Reseaech Turk.2015; 7 (4): 251-271

Ruyter Ko de, Wetzels M.On The Relationship Between Perceived Service Quality, Service Loyalty and Switching Cost.International Journal of Service Industry Management.1997; 9 (5):436-453

Stan V, Caemmerer B,Cattan-Jallet R. Customer Loyalty Development : the Role of Switching Costs. September/October 2013 [Cited 2017 Feb 25]. 29 (5). Available from https://www.cluteinstitute.com/ojs 
/index.php/JABR/article/viewFile /8069/8123.

Tjiptono F. Pemasaran Jasa. Malang : Bayumedia Publishing; 2007.

Tong C., Wong SKS, Lui KPH. The Influences of Service Personalization, Customer Satisfaction and Swiching Cost on E-Loyalty. International Hournal
Economic and Finance. 2012; 4 (3); 105-114.

Wong R., Tong C., Wong A. Examine the Effects of Customer Satisfaction on Customer Loyalty : An Empirical Study in The Healthcare Insurance Industry in Hongkong. British Journal of Economic, Management \& Trade. 2014; 4(3): 372-399 